\author{
Aleksandra Zadrożna \\ Katarzyna Chotkowska
}

Instytut Psychologii Akademii Pedagogiki Specjalnej w Warszawie

\title{
DZIAŁANIA EDUKACYJNE I WSPARCIE WOLONTARIUSZY W RUCHU SAMOPOMOCOWYM OSÓB Z DOŚWIADCZENIEM CHOROBY PSYCHICZNEJ. PRZYKŁAD GRUPY WSPARCIA TROP
}

\begin{abstract}
Educational activities and support for volunteers in the self-help movement of people with the experience of mental illness. The example of The Support Group TROP
\end{abstract}

The formation of self-help movements and support groups for mentally ill people has initiated changes in social attitude towards them and in mental health treatment system. In Poland, such initiatives are still in the initial phase of creation, there are only a few such groups. Self-help groups in general provide support by sharing emotions and a sense of understanding connected to experiencing similar problems. One of the most important functions of self-help groups is spreading reliable knowledge about specificity of mental disorders and the recovery process. Educating through direct contact with a mentally ill person is associated with a better understanding of them, as well as a lower level of stigmatizing convictions. One of the examples of a resilient self-help group is the Support Group TROP which is working in Warsaw. Its members conduct numerous educational activities that constitute a significant part of the Groups activity. These activities include lectures for pupils, students, and organizations, presentations at conferences or appearances in the media. From the beginning of TROP Group existence, all activities have been supported by volunteers - psychology students. Volunteers through non-paid work can deepen knowledge about the functioning of self-help movement and the situation of mentally ill people, and at the same time support group members in several initiatives. Volunteers have become a permanent and very important part of all implemented projects. Members of TROP describe volunteers as allies.

Key words: self-help, education, voluntary work, mental health

\section{Specyfika grup samopomocowych osób chorujących psychicznie}

W zorientowanej na samodzielność i osiągnięcie podmiotowości koncepcji procesu zdrowienia duże znaczenie przykłada się do działania grup samopomocowych (Dobrowolska, Izydorczyk 2016). Osoby z doświadczeniem kryzysu psychicznego budują nową jakość w systemie wsparcia (Bronowski, Chotkowska 2016). Dzięki ruchom samopomocowym 
możliwe było zapoczątkowanie dyskusji dotyczącej koncepcji umacniania i procesu zdrowienia i dokonanie znaczących zmian w sytuacji osób chorujących.

Według Caplana (1987) wśród specyficznych cech grup samopomocowych należy wymienić unikatowość każdego uczestnika w grupie, ich osobisty poziom wzajemnego zainteresowania, udzielanie wsparcia, wrażliwość na potrzeby, a także doradzanie dotyczące konkretnych sposobów działania w zrozumiałym dla członków grupy języku (tożsamym dla danej grupy problemów). Podjęcie aktywności i działanie na rzecz innych są jednymi z ważniejszych aspektów dochodzenia do zdrowia w chorobach psychicznych. Według Riessmana i Carolla (2000) wszystkie formy aktywności samopomocowej są korzystne dla zdrowia psychicznego. Grupy samopomocowe zapewniają wsparcie poprzez dzielenie się swoimi emocjami i poczucie zrozumienia w związku z przeżywaniem podobnych problemów. Ich cechą charakterystyczną jest skupienie się na potencjale i zasobach jednostki (Juros 1999). Grupy takie, mimo podobnych właściwości (np. korzystanie z zasobów uczestników, zasada wewnętrznej równości, współodpowiedzialności, a także swobody wymiany myśli i uczuć), jednoczą osoby o różnym rodzaju trudności (Jacobs, Goodman 1989: 573-578, za Juros 1999). Istnieją grupy samopomocowe, które skupiają się przykładowo na udzielaniu wsparcia emocjonalnego i informacyjnego, inne działaja aktywnie na rzecz poprawy możliwości funkcjonowania w społeczeństwie, zmiany statusu i postaw społecznych lub też kierują swoją aktywność na zmianę sposobu zachowania (Levy 1987). Każde z tych zadań zawiera w sobie elementy edukacyjne.

Jedno z podstawowych założeń grup samopomocowych mówiące o równości ich członków (Bąbska 2005) gwarantuje każdemu uczestnikowi dostęp do zasobów i aktywności grupy. Można do nich zaliczyć działania wewnętrzne i zewnętrzne. Jednym z działań skierowanych "na zewnątrz" może być szeroko rozumiana edukacja o trudnościach i problemach członków grupy. Kondradzka-Szala (2015) podkreśla, że samopomoc opiera się na aktywności niosącej ze sobą dawanie porad, dzielenie się informacjami oraz przeciwdziałanie osamotnieniu i zapewnienie wsparcia. Mechanizm funkcjonowania samopomocy gwarantuje możliwość dzielenia się swoim doświadczeniem, a tym samym edukowanie i propagowanie prawdziwej wiedzy dotyczącej chorób psychicznych i funkcjonowania osób z doświadczeniem kryzysu psychicznego.

Wyjątkową cechą edukacji prowadzonej przez członków grup samopomocowych jest to, że przekazywana przez nich wiedza płynie z osobistych przeżyć. Jak zaznaczają Riessmann i Carroll (2000), wiedza ta ma podwójny charakter: jest jednocześnie subiektywna oraz doświadczalna. Oprócz wielu charakterystyk wewnętrznych uczestników grup samopomocowych ich ogromnym zasobem jest doświadczenie i wiedza na temat własnych trudności. Osoby z doświadczeniem kryzysu psychicznego zjednoczone w grupie samopomocowej są ekspertami od własnych, a jednocześnie wspólnych problemów. Dzięki bezpośredniej wiedzy zdobytej w ciągu procesu zdrowienia, mogą one stać się edukatorami dla innych chorych, profesjonalistów (psychologów, psychiatrów, pracowników socjalnych), a także całego społeczeństwa.

Działanie oparte na własnym potencjale i umiejętnościach prowadzi do umocnienia jednostki (Juros 1999). Osoba z doświadczeniem kryzysu psychicznego wspierająca 
i edukująca innych przyjmuje rolę dawcy pomocy, a nie tylko jej biorcy (Bąbska 2005). Zmiana roli z zależnego, biernego pacjenta, który ma ograniczone możliwości rozwoju, na sprawczą jednostkę, przekształcającą przeżywanie choroby na doświadczenie, które staje się dla niej zasobem i może pomóc innym, pozwala wyjść poza chorobę. Ta podwójna funkcja działania w grupie samopomocowej polega na tym, że udzielanie pomocy (czy to przez dzielenie się wiedzą, czy przez inne formy oddziaływania) niesie oczywiste korzyści dla odbiorców (np. osób chorujących), ale także dla dawców (ekspertów po kryzysie). Dzielenie się własną wiedzą i wspieranie innych daje poczucie sprawstwa, kompetencji, podwyższa samoocenę.

Jak zaznacza Glinowiecki (2014), dzięki zmianom w polskim systemie wsparcia dla osób chorujących psychicznie i pojawieniu się wielu form środowiskowych osoby doświadczające trudności w zakresie zdrowia psychicznego odzyskują możliwość wchodzenia w role sprzyjające zdrowieniu. Wiążą się one zarówno z życiem prywatnym, jak i zawodowym. Oprócz form pracy chronionej lub na wolnym rynku, coraz częściej osoby chorujące zatrudniane są jako współpracownicy profesjonalistów z dziedziny ochrony zdrowia psychicznego. Ich rolą może być dawanie wsparcia, w tym informacyjnego (przekazywanie wiedzy, edukacja), doradztwo i wiele innych (Pitt, Lowe, Hill, Prictor, Hetrick, Ryan, Berends 2013).

Jak zaznacza Meder (1996), grupy samopomocowe zwykle działają w ramach sektora pozarządowego. Inicjatywy podejmowane przez te grupy są, zdaniem autorki, działaniami na rzecz zdrowia i jego ochrony umiejscowionymi dość niezależnie od działań instytucji państwowych. Załuska (1998) wymienia kilka funkcji, jakie spełniają organizacje pozarządowe: afiliacyjna, ekspresyjna, pomocowa, integracyjna, opiekuńczo-wychowawcza. Dodaje, że grupy samopomocowe (jako formy pozarządowe) mogą pełnić rolę normalizacyjną, stanowić grupy nacisku i uspołeczniające państwo. Z kolei Irena Lepalczyk (Pilch, Lepalczyk 1993: 188-109) klasyfikuje funkcje organizacji pozarządowych następująco: wspomaganie rozwoju, przygotowanie do pełnienie ról (społecznych i zawodowych), wzbogacanie życia, a także upowszechnianie wiedzy. Jak widać, jedną z ważnych ról grup samopomocowych jest działanie na rzecz upowszechniania wiedzy, wychowywania, edukowania społeczeństwa i modelowanie określonych postaw względem zjawisk (np. choroby psychicznej).

\section{Działania edukacyjne prowadzone przez grupy samopomocowe}

Szereg działań edukacyjnych można zaliczyć do formy wsparcia informacyjnego czy instrumentalnego. Wsparcie informacyjne polega na przekazywaniu treści w toku komunikacyjnej interakcji. Informacje te pomagają w lepszym zrozumieniu trudności i sytuacji, w jakiej znajduje się konkretna osoba. Instrumentalny aspekt wspierania polega na dostarczeniu konkretnych wskazówek, które są pomocne w radzeniu sobie z problemem (Kondradzka-Szala 2015). Wsparciem informacyjnym jest także dzielenie się swoimi doświadczeniami związanymi z chorobą, co stanowi częstą formę 
aktywności grup samopomocowych (Heszen, Sęk 2007). Edukacyjny wymiar grup samopomocowych może być bardzo skuteczny. W tym kontekście podkreśla się także istnienie wielu przesłanek mówiących o przewadze samopomocy (rozumianej jako forma pomocy nieprofesjonalnej) nad pomocą udzielaną przez profesjonalistów. Należy do nich zaliczyć: poczucie bycia akceptowanym i szanowanym, możliwość potwierdzania własnych poglądów i postaw w kontakcie z innymi, poczucie bezpieczeństwa, budowanie pewności siebie w sytuacjach trudnych, nabycie przeświadczenia o życzliwości świata.

Edukacja prowadzona przez grupy samopomocowe może przybierać różny charakter. Występuje m.in. w formie prowadzenia prelekcji destygmatyzacyjnych wśród określonych grup odbiorców, może być również przekazywaniem praktycznej wiedzy i wskazówek pomiędzy uczestnikami grupy. Innym jej rodzajem jest rola aktywnych doradców do spraw zdrowia psychicznego. Sherman i Porter (1991) podają przykład przeszkolonych do roli case management osób chorujących psychicznie, które brały udział w projekcie rehabilitacji psychiatrycznej pacjentów. Autorzy podają, że po dwuletniej obserwacji znacząca część doradców utrzymała swoją pracę, a liczba ich hospitalizacji była bardzo niska. W przytoczonym przykładzie nakreśla się podwójną rolę działania edukacyjnego. Z jednej strony osoba doświadczająca danego problemu dzieli się swoją wiedzą, wpływa na lepsze, bardziej realistyczne i prawdziwsze rozumienie jej sytuacji przez odbiorców. $\mathrm{Z}$ drugiej działanie w roli eksperta może być formą autoterapii, dawać poczucie sprawczości i wartości własnej osoby. Choroba zwykle jest trudnym doświadczeniem, zarówno dla jednostki, jak i jej otoczenia. Uczynienie z doświadczenia choroby zasobu, którym można się dzielić, jest krokiem pozwalającym na wyjście poza nią i przedefiniowanie roli osób doświadczających kryzysu.

Dobrym przykładem efektywnych działań nakierowanych na edukację jest program, w którym odpowiednio przeszkolone osoby chorujące psychicznie edukowały pielęgniarki w zakresie specyfiki radzenia sobie z chorobą. Taka forma oddziaływania znacząco wpłynęła na wiedzę i jakość praktyki zawodowej personelu medycznego. Przekazywanie informacji przez osoby chorujące psychiczne, skutkujące uwrażliwieniem na innych chorych, można uznać za pozytywne i korzystne (Happell, Roper 2003).

Wood i Wahl przeprowadzili badania skuteczności edukacji prowadzonej przez osoby z doświadczeniem kryzysu psychicznego (consumers) w porównaniu z profesjonalistami z systemu lecznictwa psychiatrycznego. Podczas badania mierzono wiedzę i nastawienie do chorób psychicznych. Wyniki pokazały istotnie wyższe wskaźniki dotyczące wiedzy i korzystniejsze względem chorych postawy w grupie, w której edukację prowadziła osoba doświadczająca choroby (Wood, Wahl 2006).

Kolejnym przykładem działań nakierowanych na efektywność rozpowszechniania wiedzy opartej na doświadczeniu jest przytaczany przez Cechnickiego (Cechnicki, Liberadzka 2012) udział niemieckiego stowarzyszenia zrzeszającego osoby z doświadczeniem kryzysu psychicznego (Towarzystwo Osób Doświadczonych przez Psychiatrię) w seminariach edukacyjnych o psychozie w roli partnerskiej wobec profesjonalistów. Inne badania pokazały, że edukacja odbiorców poprzez bezpośredni kontakt z osobą 
chorą psychicznie wiąże się z lepszym ich rozumieniem, a także mniejszym poziomem przekonań stygmatyzujących (Liberadzka, Szuba, Cechnicki, Kaszyński, Bielańska 2011).

Jak już wspomniano, jednym $\mathrm{z}$ aspektów samopomocy jest nacisk na działanie na rzecz innych osób. Reguła terapeutycznego oddziaływania pomocy zakłada, że największe korzyści z działań pomocowych ma ten, kto ich udziela (Riessmann, Caroll 2000). Jest to mechanizm każdej formy działania grup samopomocowych, w tym tych nastawionych na edukację społeczną. Osoba chorująca psychicznie (ekspert przez doświadczenie) ma wiedzę, która może pomóc w zrozumieniu choroby, trudności z nią związanych i różnych aspektów funkcjonowania w kryzysie. Ekspert przez doświadczenie dzieli się tym, co sam przeżył i przeanalizował (praktyczna wiedza dotycząca sposobów radzenia sobie, prawdziwy obraz choroby psychicznej). Dzięki temu inni zwiększają swoją wiedzę, a dzieląca się przeżyciami osoba ma poczucie przydatności i sprawstwa.

W Polsce ruchy samopomocowe osób z doświadczeniem kryzysu psychicznego nie są tak dobrze rozwinięte jak w Europie i Stanach Zjednoczonych i mają charakter raczej lokalny niż centralny. Jednak w trakcie ostatnich lat zauważa się powolny rozwój tej formy aktywności osób dążących do zdrowienia. Przykładem grupy samopomocowej, która w ramach swej rozbudowanej działalności prowadzi również wiele działań edukacyjnych, jest Grupa Wsparcia Osób z Doświadczeniem Kryzysu Psychicznego TROP. Działa ona na terenie Warszawy i okolic, zrzeszając osoby chorujące psychicznie, które decydują się zmieniać sytuację innych osób doświadczających kryzysu psychicznego poprzez udzielanie im wsparcia oraz wpływanie na opinie i postawy w społeczeństwie. Grupa ta funkcjonuje pod patronatem Wydziału Stosowanych Nauk Społecznych Akademii Pedagogiki Specjalnej w Warszawie. Grupa TROP związana jest ze środowiskiem naukowym i akademickim, co znacząco pomaga w wypełnianiu roli edukacyjnej. TROP podejmuje szereg działań przekazujących wiedzę i wsparcie informacyjne. Swoim zasięgiem obejmują one zarówno inne osoby z doświadczeniem kryzysu psychicznego, profesjonalistów i studentów, jak i grupy zawodowe związane z zadaniami pomocowymi.

Jednym z działań Grupy o wymiarze edukacyjnym są prelekcje dla uczniów, studentów i organizacji. Podczas prelekcji ekspert przez doświadczenie opowiada o chorobie, swoich przeżyciach, dzieli się cenną wiedzą o obrazie kryzysu. Ze szczegółami opisuje proces zdrowienia, swoje funkcjonowanie w różnych momentach tego procesu. Opisuje subiektywną perspektywę choroby, to, jak on ją odczuwa i jak jej doświadcza. Opowiada także o tym, co pomaga w przezwyciężaniu trudności, jaką rolę w tym może odgrywać środowisko społeczne. Odbiorcy mogą poznać specyfikę tego, czego nigdy nie doświadczyli, lub lepiej zrozumieć coś, z czym zmagają się oni lub ich bliscy. Jest to niepowtarzalna możliwość dla odbiorców, aby zdobyć prawdziwe informacje od osoby, która doświadczyła choroby. Prelekcje są okazją do bezpośredniej interakcji z osobą doświadczającą kryzysu, dają możliwość zadawania nurtujących pytań i weryfikowania prawdziwości swoich przekonań. Grupa TROP przeprowadziła wiele prelekcji dla uczniów, studentów i różnych organizacji. Prelekcje te przyczyniają się do obniżenia poziomu stygmatyzacji osób chorujących psychicznie i szerzą rzetelną wiedzę. Tym samym wpływają na zmianę postaw społecznych. 
Członkowie TROP-u pełnią również rolę Edukatorów Praw Obywatelskich (po przeszkoleniu w ramach kursu zorganizowanego przez Biuro Rzecznika Praw Obywatelskich). W ramach tej aktywności uczą osoby chorujące o ich prawach, możliwościach ich egzekwowania, instruują o zasadach równego traktowania. Innym działaniem Grupy są wystąpienia w mediach - uczestnicy propagują wiedzę o chorobach psychicznych, pokazują prawdziwy obraz funkcjonowania osoby po kryzysie psychicznym, dzielą się wiedzą dotyczącą sposobów wspierania.

Grupa TROP jest zaangażowana również w przygotowywanie publikacji. Wydaje między innymi „Biuletyn TROPiciel”, w którym osoby chorujące mogą podzielić się swoim doświadczeniem i przemyśleniami. $\mathrm{Z}$ ich udziałem powstał także unikatowy Poradnik - Informator będący platformą wiedzy i przydatnych wskazówek dla osób chorujących, ich rodzin, a także profesjonalistów. Osoby z Grupy Wsparcia TROP będące Doradcami Telefonicznymi prowadzą konsultacje dla chorujących i ich rodzin. Wspierają innych emocjonalnie i informacyjnie. Grupa TROP obecna jest także na konferencjach. Głos uczestników jest słyszany podczas wielu ważnych wydarzeń naukowych.

Poza korzyściami dla odbiorców działań Grupy TROP, sami uczestnicy wiele wynoszą z takich aktywności. Dzięki wychodzeniu do innych przełamują swoje subiektywne ograniczenia, a publiczne wystąpienia pozwalają im zmniejszyć lęk przed sytuacjami społecznymi (Bronowski, Chotkowska, Bednarzak 2016). Stykanie się z pozytywnym odbiorem działań umacnia ich jako osoby, daje nadzieję na zmiany, przyczynia się do budowania pozytywnego obrazu samego siebie i zachęca do dalszego brania odpowiedzialności za własny proces zdrowienia.

\section{Zaangażowanie wolontariuszy we wspieranie ruchu samopomocowego}

Zarówno w działaniach edukacyjnych, jak i w innych sferach aktywności grup samopomocowych ważną rolę odgrywają wolontariusze. Wspierają oni osoby po kryzysach psychicznych w realizowanych już działaniach i często motywują do kolejnych posunięć, oferując swoją pomoc. Biorąc pod uwagę doświadczenia jednej z grup samopomocowych osób z doświadczeniem kryzysu psychicznego - Grupy Wsparcia TROP - wolontariusze stali się trwałą i bardzo istotną częścią realizowanych działań. Członkowie TROP-u określają ich jako sojuszników.

Znaczenie wolontariuszy dla powstawania i rozwoju grup samopomocowych jest nie do przecenienia. Ustawa z dnia 24 kwietnia 2003 roku o działalności pożytku publicznego i wolontariacie określa, iż wolontariusz jest to osoba fizyczna, która ochotniczo i bez wynagrodzenia wykonuje świadczenia na zasadach określonych w ustawie. Według Centrum Wolontariatu wolontariat to świadoma, dobrowolna działalność podejmowana na rzecz innych, wykraczająca poza więzy rodzinno-koleżeńsko-przyjacielskie (www. ngo.pl, dostęp: 8.03.2018). Natomiast Ogólnopolska Sieć Centrów Wolontariatu opisuje wolontariuszy jako ludzi, którzy dobrowolnie i bez wynagrodzenia niosą pomoc, angażują 
się w pracę na rzecz innych osób i instytucji działających w różnych dziedzinach życia społecznego (www.wolontariat.org.pl, dostęp: 9.03.2018). Z usług wolontariuszy mogą korzystać między innymi organizacje pozarządowe, stowarzyszenia jednostek samorządu terytorialnego, spółdzielnie socjalne, osoby prawne i jednostki organizacyjne kościoła katolickiego i innych kościołów lub związków wyznaniowych oraz organy administracji publicznej, a także placówki oświatowe, instytucje kultury i jednostki organizacyjne pomocy społecznej (Bobek, Żołędowska 2011). Największa grupa wolontariuszy angażuje się w działalność sektora non-profit, stowarzyszeń, organizacji społecznych i fundacji (GUS 2016).

Motywacje wolontariuszy bywają różne: może to być chęć zdobycia doświadczenia zawodowego, pozyskanie nowych umiejętności, chęć samorealizacji i akceptacji (Pulińska 2012). Działalność wolontariacka najczęściej jest podejmowana dla przyjemności, z powodu wyznawanego podglądu o wzajemności pomocowej, wyznawanych wartości, dla możliwości przebywania z innymi ludźmi, nawiązania kontaktów, a także w związku $\mathrm{z}$ chęcią zdobycia nowych umiejętności. Wolontariusze, kierując się swoimi motywacjami i możliwościami, wybierają różne aktywności w ramach świadczenia nieodpłatnej pracy - mogą to być prace organizacyjne lub bezpośrednio z potrzebującymi osobami. Niektórzy wolontariusze wybierają udział w działaniach akcyjnych, inni angażują się na dłużej w działania jednej grupy czy organizacji.

Wolontariusze często włączają się w prace na rzecz tych, którzy potrzebują wsparcia, dzieci, osób starszych, niepełnosprawnych. Jedną z grup, która korzysta z pomocy osób świadczących swoją pracę nieodpłatnie, są osoby chorujące psychicznie. Brak jest danych dotyczących liczby wolontariuszy wspierających takie osoby w Polsce. Natomiast wiadomo, iż w jednym z regionów Austrii zamieszkanym przez 1,2 miliona osób jest grupa 298 wolontariuszy, która pracuje bezpośrednio z osobami chorującymi psychicznie. Z kolei jedna z organizacji działających na rzecz osób chorujących psychicznie we wschodnim Londynie w ciągu pierwszych miesięcy działania zaangażowała 250 nowych wolontariuszy (Hallet, Klung, Lauber, Priebe 2012). Z powodu braku takich danych z Polski nie ma możliwości porównania skali zaangażowania osób w pracę wolontariacką.

Doskonałym przykładem współpracy z wolontariuszami są działania samopomocowej Grupy Wsparcia TROP. Korzysta ona ze wsparcia wolontariuszy od początku swojego istnienia. Grupa została utworzona przez osoby po kryzysie psychicznym w 2013 roku i działa w ramach Porozumienia na Rzecz Wspierania Osób Chorujących Psychicznie. Na początku istnienia Grupy wszystkie działania realizowane były całkowicie bezkosztowo jedynie przy zaangażowaniu osób chorujących i wolontariuszy. W ciągu ponad czterech lat istnienia TROP zrealizował wiele projektów finansowanych ze źródeł zewnętrznych, przy czym wolontariusze są nadal stałym elementem wspierającym wszystkie realizowane działania. Wolontariuszami są przede wszystkim członkowie Koła Naukowego Psychologii Klinicznej i Psychoterapii APSI działającego w Akademii Pedagogiki Specjalnej w Warszawie. Są to głównie studenci kierunku psychologia, co gwarantuje spełnienie wymogu zawartego w Ustawie o działalności pożytku publicznego i wolontariacie o tym, 
iż wolontariusz powinien posiadać kwalifikacje i spełniać wymagania odpowiednie do rodzaju i zakresu wykonywanych działań (Ustawa o działalności pożytku..., art. 43).

Zaangażowanie studentów w TROP-ie można podzielić na dwie kategorie: organizacyjne i zapewniające indywidualne wsparcie dla członków Grupy. W ramach działań organizacyjnych wolontariusze pomagają w organizacji spotkań Grupy, redagowaniu „Biuletynu TROPiciel”, prowadzeniu strony internetowej www.czasnaporozumienie.pl. Włączają się także w realizację bieżących projektów, pomagają w organizacji konferencji czy tworzeniu dokumentacji działań TROP-u. Natomiast działania wspierające to pomoc członkom Grupy przed ważnymi wydarzeniami, jak, przykładowo, wystąpienia na konferencjach, towarzyszenie podczas wywiadów, audycji radiowych i prelekcji oraz przede wszystkim rozmowy i wysłuchanie osób po kryzysach psychicznych. Bez wsparcia wolontariuszy rozpoczęcie pracy Grupy Wsparcia TROP byłoby wręcz niemożliwe, a prowadzone dziś działania byłyby mocno ograniczone.

Według osób chorujących psychicznie, ważną korzyścią płynącą z pracy wolontariuszy jest możliwość posiadania przyjaciela wśród osób spoza najbliższego otoczenia. Ponadto podkreślają oni, iż kontakt z kimś, kto już wiedział o ich chorobie, łagodzi niepokój odczuwany zazwyczaj podczas nawiązywania nowych znajomości (Hallet, Klung, Lauber, Priebe 2012).

Wolontariusze pełnią obowiązki nieodpłatnie, jednak ze swojej aktywności mogą czerpać wiele korzyści niefinansowych. Według badań wolontariusze pracujący z osobami chorującymi psychicznie jako korzyści ze swojej pracy postrzegają: nabywanie nowych umiejętności, poznawanie nowych ludzi, bycie akceptowanym i lubianym, zwiększenie własnej świadomości dotyczącej zdrowia psychicznego, zdobywanie doświadczenia istotnego z psychologicznego punktu widzenia (Brackhane, Strehl, Wurzer 1990). Prawdopodobnie korzyści te mają wpływ na to, iż wolontariusze pozytywnie oceniają prace z osobami chorującymi psychicznie. Aż $87 \%$ badanych wskazało, że są bardzo usatysfakcjonowani lub raczej usatysfakcjonowani swoją pracą wolontariacką i spełnili swoje oczekiwania. Co ciekawe, $33 \%$ wolontariuszy uważało, że mogą wykonać lepszą pracę niż profesjonaliści (Rossler, Horst, Salize 1996).

\section{Współpraca z Grupą Wsparcia TROP - perspektywa wolontariuszy}

Wolontariusze świadczący pomoc w Grupie TROP również czerpią wiele korzyści ze swojego zaangażowania. Przede wszystkim jest to możliwość regularnego kontaktu z osobami doświadczającymi kryzysów psychicznych. Studenci podczas obowiązkowych praktyk studenckich mają co prawda kontakt w szpitalu lub w środowiskowych placówkach wsparcia z osobami chorującymi. Jest to jednak kontakt krótkotrwały - trwający zazwyczaj nie dłużej niż trzy tygodnie. Co więcej, praktyki realizowane są zwykle z pozycji zdystansowanego obserwatora. Wolontariusze wspierający ruch samopomocowy osób chorujących mają kontakt z pacjentami regularnie. Czas znajomości i budowane stopniowo zaufanie sprawiają, że członkowie Grupy dzielą się z wolontariuszami doświadczeniem 
swojego życia z chorobą - stanowi to nieocenioną wiedzę dla przyszłych profesjonalistów. Ponadto studenci mają możliwość zaobserwowania, jak działa jedna z nielicznych w Polsce grup samopomocowych osób doświadczających kryzysów psychicznych. Jest to także okazja do nawiązania współpracy z ekspertami przez doświadczenie w dziedzinie wsparcia osób chorujących, którzy chętnie dzielą się z wolontariuszami swoją wiedzą $\mathrm{w}$ tej dziedzinie.

Współpraca wolontariuszy z grupami samopomocowymi może dać bardzo wiele korzyści. Kontakt z osobami chorującymi psychicznie, oparty na zasadzie podmiotowości, partnerstwa i umacniania, pozwala zrewidować wiele utartych przekonań i stereotypów. Możliwość praktycznego udziału we wspomaganiu działań grupy ułatwia nabycie cennych kompetencji psychologicznych. Eksperci przez doświadczenie w efektywny sposób mogą nauczyć się, jak komunikować się z innymi osobami, szanując przy tym odmienność. Ich otwartość na innych i chęć przekazywania wiedzy sprzyjają rozwijaniu postaw tolerancji i równości opartej na humanistycznym podejściu do człowieka. Dzięki kontaktom z osobami chorującymi, wolontariusze uczą się w naturalny sposób najpierw zauważać zasoby, pozytywy i potencjał i to na nich opierać relację.

Dla wolontariuszy ważna jest także możliwość rozmawiania o doświadczeniu kryzysu psychicznego z osobami, które go przebyły. Istotna jest tu również kwestia języka, jakim posługują się członkowie grupy, opisując swoje życie z chorobą. Jest to język często niezrozumiały dla osób spoza grupy, lecz bardzo ważny w aspekcie holistycznego zrozumienia człowieka doświadczającego choroby psychicznej. Możliwość współdziałania wolontariuszy z grupami samopomocowymi daje okazję do poznania ich charakterystyki i zrozumienia specyficznego języka opisującego ich rzeczywistość.

Współpraca z osobami chorującymi psychicznie nieustannie pokazuje, jak ważne jest słuchanie i dobra komunikacja. Wrażliwość na potrzeby, chęć zauważenia zasobów, otwartość i wyzbycie się postawy oceniającej są podstawami budowania relacji opartej na zaufaniu. Dopiero pewne subtelne aspekty komunikacji i budującej się relacji uwrażliwiają i pozwalają ćwiczyć kompetencje nabyte w toku formalnych szkoleń i studiów. Dzięki współpracy z członkami grup samopomocowych, wolontariusze mogą sprawdzać już zdobyte umiejętności i w praktyczny sposób uczyć się nowych. Jak sami zaznaczają, wzrasta ich poczucie pewności w kwestiach swoich kompetencji psychologicznych.

Osoby z grupy samopomocowej chętnie dzielą się praktycznymi wskazówkami. Opowiadają, co im pomaga w kryzysie i czego oczekują od profesjonalistów. Przekazują swoją wizję psychologa - kompetentnego, szanującego, przyjaznego i dającego wolność. Pozwala to na zweryfikowanie teoretycznych założeń wykonywania zawodu psychologa z kontraście z realnymi potrzebami i oczekiwaniami osób chorujących. Dzięki takiej wiedzy wolontariusze - przyszli profesjonaliści - mogą odpowiedzialnie kierować swoim rozwojem, nabywają świadomość ważnych cech i tego, czego muszą się jeszcze nauczyć.

Nawiązanie bezpośredniego kontaktu z ekspertami przez doświadczenie pozwala dostrzec pełny obraz ich funkcjonowania, wraz z wymiarem emocjonalnym, psychologicznym, społecznym, rodzinnym i zawodowym. Przekazanie własnej perspektywy, uzupełnionej kontekstem życiowych wydarzeń, umożliwia lepsze poznanie specyfiki 
wpływu choroby na człowieka i jego otoczenie. Jak podkreślają wolontariusze, współpraca z grupą wsparcia jest dla nich ważna i przełomowa, ponieważ pokazuje, że diagnoza jest tylko nazwą i swoistym uproszczeniem. Każda osoba chorująca jest unikatowa, ma swoją historię, potrzeby, marzenia i oczekiwania.

Bezpośredniość i naturalność członków grupy samopomocowej, a także gotowość do współpracy pomagają nabyć swobodę w kontakcie z osobami chorującymi psychicznie. Dzięki temu przyszli profesjonaliści uczą się postawy autentyczności i naturalności - tak ważnej we wszystkich kontaktach międzyludzkich. Przełamuje to lęk wolontariuszy, wynikający z braku doświadczenia, obawy, że nie jest się wystarczająco kompetentnym i można popełnić błąd w kontakcie z osobą doświadczającą kryzysu psychicznego.

Informacje przekazywane przez członków grupy samopomocowej uświadamiają wolontariuszom, że trzeba krytycznie patrzeć na różne źródła wiedzy. Nie należy wszystkich informacji uzyskiwanych podczas studiów przyjmować bezkrytycznie. Krytycyzm daje możliwość wyjścia poza utarte schematy myślenia (np. o chorobach psychicznych). Nabycie takich kompetencji pozwala na wyćwiczenie elastyczności w myśleniu i działaniu; kontakt z członkami Grupy bardzo w tym pomaga.

Dzięki współpracy z ekspertami przez doświadczenie wolontariusze mogą uczyć się również określania i pilnowania granic relacji. Zaczynają doceniać umiejętność konsekwentnego działania zgodnego z deklaracjami i obietnicami. Te lekcje odpowiedzialności przekładają się na rozwój osobisty przyszłego psychologa. Kompetencje tego typu są trudne do nabycia bez kontaktu z osobami doświadczającymi kryzysu. Działanie wolontariuszy w grupach samopomocowych stwarza właśnie taką możliwość.

\section{Bibliografia}

Bąbska B. (2005). Centrum aktywności lokalnej. Samopomoc - rozwiązywanie ludzkich problemów. Centrum Aktywności Lokalnej, Warszawa.

Bobek K., Żołędowska M. (2011). O czym każdy wolontariusz wiedzieć powinien? Ministerstwo Pracy i Polityki Społecznej, Warszawa; www.bibliotekawolontariatu.pl (dostęp: 21.02.2018).

Brackhane R., Strehl C., Wurzer I. (1990). Lay help in rehabilitation of psychiatrically handicapped patients. Report of two Comparative empirical studies. „Rehabilitation (Stuttgart)”, 29 (4): 254-260.

Bronowski P., Chotkowska K., Bednarzak J. (2016). Nowe trendy w rehabilitacji osób chorujących psychicznie. „Kwartalnik Niepełnosprawność - Zagadnienia, Problemy, Rozwiązania”. Państwowy Fundusz Rehabilitacji Osób Niepełnosprawnych, Warszawa.

Caplan G (1987). System oparcia, w: W. Widłak (red.), Pomoc nieprofesjonalna i grupy wzajemnej pomocy. Studium Pomocy Psychologicznej PTP, Warszawa.

Cechnicki A., Liberadzka, A. (2012). Nowe role osób chorujących psychicznie w procesie leczenia i zdrowienia. „Psychiatria Polska”, XLVI (6): 995-1005.

Dobrowolska M., Izydorczyk B. (2016). Współczesne trendy w psychiatrii środowiskowej $w$ kontekście deinstytucjonalizacji. „Społeczeństwo i Edukacja”, 21 (2). 
Dziennik Ustaw Rzeczpospolitej Polskiej, Warszawa, dnia 2 marca 2017 r., poz. 458.

Glinowiecki M. (2014). Role społeczne osób z zaburzeniami psychicznymi w ujęciu nauk społecznych. „Postępy Psychiatrii i Neurologii”, 23 (3): 128-133.

GUS - Wolontariat w organizacjach - 2016 r. Wstępne wyniki badania „Praca Niezarobkowa poza gospodarstwem domowym”. Notatka informacyjna (2016). GUS, Warszawa.

Hallet C., Klung G., Lauber Ch., Priebe S. (2012). Volunteering in the care of people with severe mental illness: A systematic review. „BCM Psychiatry”, 12: 226.

Happell B., Roper C. (2003). The role of a mental Health consumer in the education of postgraduate psychiatric nursing students: The students' evaluation. „Journal of Psychiatric and Mental Health Nursing", 10 (3): 343-350.

Heszen I., Sęk H. (2007). Psychologia zdrowia. PWN, Warszawa.

http://wolontariat.org.pl/wolontariusze/kim-jest-wolontariusz/ (dostęp: 9.03.2018).

http://poradnik.ngo.pl/jak-zaangazowac-wolontariusza (dostęp: 8.03.2018).

Juros A. (1999). Psychospołeczne uwarunkowania aktywności samopomocowej: Umacnianie Osoby, grupy i wspólnoty. „Roczniki Psychologiczne”, t. II: 125-148.

Kondracka-Szala M. (2015). Wsparcie społeczne osób stygmatyzowanych. Wirtualne grupy samopomocowe. Difin, Warszawa.

Liberadzka A., Szuba M., Cechnicki A., Kaszyński H., Bielańska A. (2011). Through education to social inclusion: The anti-stigma program implemented by community psychiatry workers and users in Krakow. „Psychiatrische Praxis”, 38.

Levy L.H. (1987). Grupy samopomocy: typy i procesy psychologiczne, w: W. Widłak (red.), Pomoc nieprofesjonalna i grupy wzajemnej pomocy. Studium Pomocy Psychologicznej PTP, Warszawa.

Meder J. (1996). Nowoczesne formy rehabilitacji chorych na schizofrenię. „Farmakoterapia w Psychiatrii i Neurologii", 12 (3): 57-61.

Pilch T., Lepalczyk I. (red.) (1993). Pedagogika społeczna. Człowiek w zmieniającym się świecie. Zakład Graficzny UW, Warszawa.

Pitt V., Lowe D., Hill S., Prictor M., Hetrick S.E., Ryan R., Berends L. (2013). Consumer-providers of care for adult clients of statutory mental health services. „Cochrane Database Systematic Reviews", 28 (3).

Pulińska U. (2012). Psychospołeczne uwarunkowania podejmowania działalności wolontariackiej. „Warmińsko-Mazurski Kwartalnik Naukowy, Nauki Społeczne”, 2: 23-40.

Riessman F., Caroll D. (2000). Nowa definicja samopomocy. „Polityka i Praktyka. PARPA”, Warszawa.

Rossler W., Horst A., Salize H.J. (1996). Voluntary aids in psychiatry. „Psychiatrische Praxis”, 23 (4): 168-171.

Sherman P.S., Porter R. (1991). Mental health consumers as case management aides. „Psychiatric Services", 42 (5): 494-498.

Ustawa z dnia 24 kwietnia 2003 roku o działalności pożytku publicznego i wolontariacie, Dz.U. z 2003 r., Nr 96, poz. 873 z późn. zm.

Wood A.L., Wahl O.F. (2006). Evaluating the effectiveness of a consumer-provided mental health recovery education presentation. „Psychiatric Rehabilitation Journal”, 30 (1): 46-53.

Załuska M., Boczoń, J. (red.) (1998). Organizacje pozarządowe w społeczeństwie obywatelskim. Wydawnictwo „Śląsk”, Katowice. 